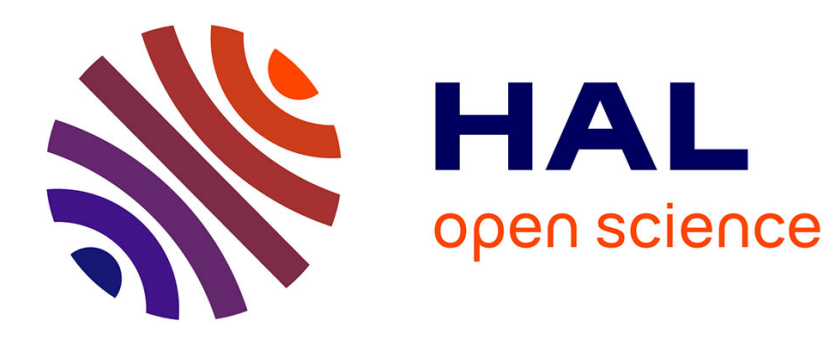

\title{
Collaboration and Empowerment in Transliteracy at School
}

\author{
Karine Aillerie, Anne Lehmans, Anne Cordier
}

\section{To cite this version:}

Karine Aillerie, Anne Lehmans, Anne Cordier. Collaboration and Empowerment in Transliteracy at School. Information Literacy in the Workplace, 2018, 978-3-319-74334-9. halshs-01599185

\section{HAL Id: halshs-01599185 \\ https://shs.hal.science/halshs-01599185}

Submitted on 26 Jun 2019

HAL is a multi-disciplinary open access archive for the deposit and dissemination of scientific research documents, whether they are published or not. The documents may come from teaching and research institutions in France or abroad, or from public or private research centers.
L'archive ouverte pluridisciplinaire HAL, est destinée au dépôt et à la diffusion de documents scientifiques de niveau recherche, publiés ou non, émanant des établissements d'enseignement et de recherche français ou étrangers, des laboratoires publics ou privés. 
5th European Conference, ECIL 2017, Saint Malo, France, September 18-21, 2017, Revised Selected Papers

Editors: Kurbanoğlu, S., Boustany, J., Špiranec, S., Grassian, E., Mizrachi, D., Roy, L. (Eds.)

Pages 315-321

\title{
Collaboration and Empowerment in
}

\section{Transliteracy at School}

\author{
Karine Aillerie ${ }^{1}$, and Anne Lehmans ${ }^{2}$, and Anne Cordier ${ }^{3}$ \\ 'Réseau Canopé/EA TECHne, Poitiers University, France \\ karine.ailleriedreseau-canope.fr \\ ${ }^{2}$ Bordeaux University, IMS, France \\ anne. lehmans@u-bordeaux. fr \\ Rouen University, ESO, France \\ anne.cordier@univ-rouen. fr
}

\begin{abstract}
Information literacy has long been considered an important aspect in school, as well as in the workplace. Teenagers are the first group affected by requirements based on information skills. Transliteracy occurs as a relevant concept to understand these information practices. Indeed, a holistic approach is needed in order to take into account the multiplicity of contexts of uses and interactions. The resarch work described here proceeds from a program funded by the French national research agency (ANR Translit 2013-2016) focusing on how high-school students (15-16 years old) manage information with all the available media and tools, individually as well as collectively. Based on ethnographic methodology, the study was carried out between November 2013 and March 2015, in five French high schools during specific learning project based activities. Findings demonstrate that activities and knowledge management on the school workplace must take into consideration complex information skills crossing personal competencies, representations, and self-esteem on one hand, school requirements and context on the other; complex social interactions during information activities; postures and spaces encouraging horizontal learning processes between teachers and students in
\end{abstract}


order to build a community of practice. Our results highlight what is directly visible and what remains implicit. They are likely to be useful for teachers as well decision-makers when designing learning scenarios and guidelines or curricula.

Keywords: transliteracy; information literacy; social interactions; community of practice; high-school.

\section{Introduction}

In the 21st century, the skills required to be successful at school as well as in the workplace involve a high number of proficiencies. These skills include information seeking and problem solving strategies, a posteriori validation of information and critical thinking, social skills and collaboration, participation and creativity [1]. Teenagers are the first to be affected by these requirements. "Complex and fascinating" [2] and deeply heterogeneous, their individual information practices beg questions. Far from the "digital natives" myth, their uses are multifaceted, distributed through juvenile socialization, daily activities, and educational requirements among others [3]. Transliteracy is found to be relevant in order to understand these information practices. As such this approach joins the theoretical and methodological contributions to a renovated definition of information literacy according to the fast-changing information world and the real practices of users in different settings. Transliteracy was initially defined by Sue Thomas and colleagues [4] as "the ability to read, write and interact across a range of platforms, tools and media from signing and orality through handwriting, print, TV, radio and film, to digital social networks". In a research project funded by the French National Research Agency, which took place in France from 2012 to 2016, we adopted a more complex definition for this notion of transliteracy. We included "information culture" in context, identifying situations of literacies, media and devices transfers. We analyzed information activity on a transliteracy based approach, while taking into account the social dimension and interactions between individuals. Finally, the researchers involved sought to highlight new forms of "information grammar" [5], transforming fragmented social knowledge into learning potential.

For this contribution, we choose to focus on data collected on the school grounds investigated in this project: five French high schools (15-16 years old students), from four different French areas, during specific learning project-based activities (10th grade, five classes of 30 pupils each). Relying on ethnographic methodology, we studied how students manage information with all the available media and tools, individually as well as collectively.

\section{Theoretical and methodological framework}


Five grounds have been investigated in senior and vocational high schools, over three years and for several weeks $(2-18)$ of observation of dedicated information research activities. During specific educational activities, students (15-16 years old) were required to collectively (by groups of $3-4$ members) produce digital outputs such as blogs, videos, travel diaries, slideshows. We aimed to take into account the "social thickness of in progress practices" [6] and then to holistically consider students' information practices and interactions, considering that Transliteracy necessarily grows within communities [7]. According to Liquète [7], the "trans" prefix means in the same time transversal (across different fields of knowledge), and transformation, from uses and practices to knowledge. Thus we have adopted an ecological approach in order to emphasize the role of global context (media and devices available, time and locations where the work took place, collective organizations, teachers' requirements and monitoring) in which one builds its relation to information. On the basis of the "situated" and "distributed" cognition approach [8] [9], we aimed to take into account students and teachers' real uses and their representations. To embed this question of contexts, a multidimensional protocol was set up based on an ethnographic observation involving cross-methodologies: application of an observation grid common to all the fields of investigation, audio recording of the observed situations, pictures, collection of traces (e.g. pupils' productions, drafts and organizational documents, roadmaps provided by teachers, discussions on Facebook, online collaborative documents), students and teachers' interviews. Researchers, alone or in pairs, conducted non-participatory observations, kept a journal of research and carried out flexible exploratory interviews [10] throughout the observed activity, in order to better understand actors' decisions at the moment.

Regarding the elements of observation, each researcher focused mainly on the context of action (dedicated working time, extensions outside the observed situation), the distribution of work within the groups, the individual as well as collective ways to search for information, interactions between pupils, pupils and teachers and between teachers, assessment criteria, the mobilization of various media and tools and moments of transition from one to another. During the observations, we moved regularly from a broad perspective to a narrow one, focusing on a single group, activity or interaction, and then returning to a view of the overall situation [11].

\section{$3 \quad$ Key results in analyzing and processing information from a Transliteracy-based perspective}

\subsection{Spaces as a framework for interactions}

Different school contexts were investigated. High-school libraries appeared to be a particularly legitimate and legitimating space for new forms of interactions and interdisciplinarity activities. Teachers and pupils expressed the feeling of being empowered within this specific teaching and learning place, building relationships 
with each others and working differently than in a regular classroom. A student explained: "When we are in the school library, we work all together, we exchange much more about what we do and how we do it". Other places at school could have been investigated as well (corridors or self-access rooms for instance). We have also observed horizontal relationships between pupils and teachers, who were satisfied to "learn beside and sometimes from their pupils", as witnessed by an English teacher. It could have been assumed that the computer rooms would have been also favored by the actors, regarding digital projects. In fact, the interactions appeared to be impeded there: the inflexible organization arrangement of this kind of places does not favor multi-layouts and group work (space occupied by a computer on a narrow desktop, layout of computers in blocks, for instance), accentuating the division of labor.

In an observation carried out on a school trip abroad, we were especially able to measure the need to take into account the porosities between different contexts in informational situations. The school space extended into the social space when the school librarian precisely invited the students to collect information all over the city, involving the use of personal devices such as mobile phones or tablets. Thus, "intermediate spaces" [12] between school and personal life, face-to-face as well as remote, can support transliteral practices. Moreover, we have been able to observe, even within activities located at school, a strong externalization of interactions among students, especially through the uses of social networking sites and online collaborative tools. Those are pretty much compatible with regulation of group work and the coordination of tasks.

\subsection{The complexity of collective organizations}

There is a significant difference among teachers depending on their teaching profiles. There are those who assimilate group work with independence and "non-intervention", and those - often school librarians - who view these kinds of projects as an opportunity to promote information literacy activity as a priority. There is, however, a general consensus that there is a need for teacher's attitudes to change. Reduced interventions could be used to encourage interactions among pupils as well as to enhance skills acquired out of school. We have actually observed that teachers mostly allowed groups to organize themselves as they could. This leads to a division of tasks that is carried out according to the media types (e.g. one student searching on the Web, another searching on the library database, another consulting dictionaries, etc.). Transliteracy is therefore not spontaneous, far from it. On the other hand, teachers' monitoring of students' activity is always carried out by the setting up of "boundary objects" [13] such as roadmaps, logbooks or even tutorials, which can be considered as "documents for action" [14].

It is moreover noticeable that an essential factor for activity regulation is the identification by the pupils themselves of their own expertise. For example, a storyboard was spontaneously produced by the group members in order to organize the tasks according to the skills which are individually assigned (bibliography, technical aspects, knowledge organization). A social circulation of the expertise was 
thus observed among students, who constantly verbalized their actions. As such, social networking sites and online collaborative tools play a great role in collective organizations, especially outside school time as mentioned above. As a result, students tend somehow to confuse the tools used with the organization itself. For instance, "we did a Google doc, Sir!" answered a student when a teacher asked how the group implemented the organization.

\subsection{Interactions, skills and knowledge}

The outputs of interactions (e.g. digital outputs provided by pupils on teachers' requirement) shed light on the identified expertises and tasks which have been distributed within groups. We must point out that the interweaving of different codes (e.g. image, text, sound) was an assessment criteria constantly repeated. We are then not able to assume that the pupils' outputs would have been spontaneously multimedia without this academic demand. In any case, digital outputs highlighted once again skills heterogeneity among pupils and the significant importance of extra-curricular time in the collective organizations. Such an observation leads to question the role of these outputs in the amplification of inequalities among pupils. Indeed, outputs were most often carried out on free time. Then personal devices owned at home as well as technical and informational skills that teenagers already gained, become a major factor of success and distinction. Teachers however must be able to support and train pupils in the classroom or school place in order to formalize and structure knowledge, especially regarding specific requirements such as the diversity of media types employed providing outputs.

Observations demonstrated that skills were largely transformed within the group. Group work allowed for the emergence of a relative complementarity between individuals, either in terms of the distribution of tasks according to the skills and capacities assumed by each member, including leadership effects, or in terms of transfers of expertise from one individual to another or to the whole group. This did not necessarily encourage individual learning, as students may remain confined within or outside their areas of expertise. The distribution of skills and knowledge within the groups was based on three points: collection of information, writing and synthesis, communication. Several and multimedia combinations affected reading and writing tasks: on-screen reading and writing (taking notes) on paper, reading and writing on computer or on paper, reading on paper and writing on computer or even on a phone. In these strategic and cognitive configurations, tools and spaces, personal as well as academic, play indeed an important role.

\subsection{The conditions of a possible distributed literacy}

Forms of "distributed cognition" exist when interaction between cognitive technologies linked to a particular environment (a workspace for example) and exchange spaces linked to social arrangements (in a type of task required) create 
collaborative learning modes [9]. Spaces, media types, devices, finding and processing information methods, can be considered as informational tools. High school students can use a very wide range of tools that are likely to allow them to vary the methods of information access and processing. The choice of tools, and especially ways one uses them, depends initially on what the social environment, firstly at home, offers to each student, even if the statistics show in France a global high rate of digital equipment. School have then to democratize tools and ways to use tools, that students do not usually use, or even know, on a daily basis, especially in three main areas: information seeking (catalogs), information storage and management (indexation), processing and communication (publishing tools). As pupils tend to work a lot outside of school time, special attention must be paid to spaces and settings. They may use public spaces (libraries or school libraries) to continue their work, while they may also have to be satisfied with what they find at home, "information fluent" or not.

\section{Conclusions}

Our findings highlight that the notion of Transliteracy is built on five key points: the relation to the group (social factor), the relation to semio-technical contexts (spaces, media, devices, procedures for finding and processing information), the relation to legitimacy (cultural factor), the relation to time (temporal factor) and knowledge format (cognitive factor). These elements require particular attention in the context of information literacy strategies.

Activities observed show that the broadest divide is between school culture and individual information practices. On the teachers' side, students' technical abilities are often overestimated. The consequence is a discrepancy between expected and real digital skills [15]. This persistent overestimation tends however to neglect actual learning needs, even basically technical ones. This is a key point, useful for the information literacy field of research as well as for educators. For instance students see their teachers as not technically experts but as information validating experts in relation to educational requirements. They are therefore often requested to help in this validation stage, whereas there is a paradoxical injunction of independence since pupils are summoned to be experts and critics without necessarily having all the cognitive tools to do so. These shifts can slow down group dynamics or creativity. Moreover, whether French high-shool pupils still need to improve their proficiency in validation of information and critical thinking, teachers' recommendations are likely to replace pupils' personal reflection. Our findings, and the theoretical angle we choose to implement, highlight the gap between actual cognitive processes and the representation of legitimate knowledge. More precisely, a bridge is to be built between the informational universe of the Web, moving and fuzzy, and the school universe that structures communication, formats and legitimacy.

The ability to manage free time and to work outside schooltime is very unequal [16]. 
Working outside classroom or schooltime, remotely, requires a pupil's know-how, in the sense of Coulon [17]. It does not only depend on technical skills or mastery of tools, but on a consistent level of self-esteem to take ownership of working methods: e.g. connecting to the school's VLE, consulting documents and taking enough time to learn, in a process of affiliation to the group or class and its activities. As collaborative learning and group work are a major requirement of current education programs, our results point out how much sharing tasks could be time consuming for students leading to reduced cognitive effectiveness. This dilution can be offset by social exchanges between peers, and the emergence of expertise distributed in working groups around certain media such as the blog.

The daily digital tools make it possible to rely on familiar communication formats, common to daily uses as well as academic ones: lists, collections, index, for instance featured on social networking sites or blogs. It is an opportunity for students to create their own spaces-time of socialization and learning, different from the strict time and space frame imposed by school. Our transliteracy based-approach point out that it has to be managed by teachers however. Teenagers are used to listening to music and working at the same time, managing personal and academic purposes at the same moment even with the same tools. The knowledge format remains a benchmark that makes it possible to distinguish what belongs to the content of the knowledge included in a specific and imposed form and that what belongs to the context of learning. The proposal of varied knowledge formats allows the setting up of communication conditions and provides a framework facilitating the emergence of transliteracy skills. The logbook for example, is rather usual in the French educational system and required in activities, but is actually often reduced to a formal and unefficient pedagogical tool. The logbook can however become a real cognitive and didactic tool for training, for storing, sharing and documentarizing collected information. Finally, a specific communication format (for example video) makes it possible for pupils to think about alternative outputs or ways of communication and to reduce the contradictions they perceive between familiar multimedia arrangements and constrained school formats (for example dissertation). The design of information through production of content can also be seen as a mode of grammatization of uses based not only on the procedures but also the critical reflection, not only on problem solving but also on the discovery of questions.

Regarding the keys factors mentioned above, Transliteracy is likely to be facilitated by group work and the multiplication of tools, but rather obstructed by cultural constraints: representations of what is legitimate or not, expressed in traditional knowledge formats. On this matter of cultural construction, representations and construction of meaning, the role of the teacher becomes essential for the emergence of forms of Transliteracy.

\section{References}


1. Voogt, J., Roblin, N.: A comparative analysis of international frameworks for $21 \mathrm{st}$ century competences: Implications for national curriculum policies, Journal of Curriculum Studies, 44, 3 (2012), 299-321

2. boyd, d.: It's complicated: the social lives on networked teens. New Haven \& London, Yale University Press (2014) https://www.danah.org/books/ItsComplicated.pdf

3. Cordier, A.: Grandir Connectés : les adolescents et la recherche d'information. Caen, C \& F Éditions (2015)

4. Thomas, S., Joseph, C., Lacetti, J., Mason, B., Mills, S., Perril, S., Pullinger, K.: Transliteracy: Crossing divides, First Monday, 12, 3 (2007) http://firstmonday.org/article/view/2060/1908

5. Chervel A: Histoire de la grammaire scolaire. PBP édition (1981)

6. Jeanneret, Y, Souchier, E, Le Marec, J.: Lire, écrire, récrire ? Paris, Bibliothèque publique d'information (2003)

7. Liquète, V.: Can one speak of an "Information Transliteracy"?. In: Unesco-Ifap, International Conference Media and information literacy for knowledge societies, Moscow, Russia, June 24-28 (2012)

8. Conein, B., Jacopin, E.: Action située et cognition : le savoir en place, Sociologie du Travail, 36, 4, 475-500 (1994)

9. Conein, B.: Cognition distribuée, groupe social et technologie cognitive, Réseaux, 2, 53-79 (2004)

10. Vermersch, P. L'entretien d'explicitation enformation initiale et continue. Paris, ESF (1994).

11. Grosjean, S.: Étudier la dimension sensible des savoirs produits en contexte de travail, Études de communication, 42 (2014)

12. Cottier, P., Burban, F.: Le lycée à l'ère numérique: usages et recomposition des acteurs, Toulouse, Octares (2016)

13. Star, S.L., Griesemer, J.: Institutionnal ecology, 'Translations', and Boundary objects: amateurs and professionals on Berkeley's museum of vertrebate zoologie, Social Studies of Science (1989)

14. Dalbin, S., Guyot, B.: Documents en action dans une organisation : des négociations à plusieurs niveaux, Études de Communication, 30, 55-70 (2007)

15. Dioni, C. Métier d'élève, métier d'enseignant à l'ère numérique : Rapport de recherche pour l'INRP (2008) http://hal.archives-ouvertes.fr/docs/00/25/95/63/PDF/rapportrecherche0208.pdf

16. Le Douarin, L.: Une sociologie des usages des TIC à l'épreuve du temps libre : le cas des lycéens durant l'année du baccalauréat, Recherches en éducation, 18, 11-26 (2014)

17. Coulon, A.: Un instrument d'affiliation intellectuelle, Bulletin des Bibliothèques de France, 44, 1, 36-42 (1999) 